Article

\title{
Divergent Regulation of Myotube Formation and Gene Expression by E2 and EPA during In-Vitro Differentiation of C2C12 Myoblasts
}

\author{
Orly Lacham-Kaplan ${ }^{1, *}$, Donny M. Camera ${ }^{2}$ and John A. Hawley ${ }^{1}$ \\ 1 Exercise and Nutrition Research Program, Mary Mackillop Institute for Health Research, Australian Catholic \\ University, Melbourne 3000, Australia; john.hawley@acu.edu.au \\ 2 Department of Health and Medical Sciences, Swinburne University of Technology, Melbourne 3122, \\ Australia; dcamera@swin.edu.au \\ * Correspondence: Orly.lacham-kaplan@acu.edu.au
}

Received: 23 December 2019; Accepted: 21 January 2020; Published: 23 January 2020

\begin{abstract}
Estrogen (E2) and polyunsaturated fatty acids (n-3PUFA) supplements independently support general wellbeing and enhance muscle regeneration in-vivo and myotube formation in-vitro. However, the combined effect of E2 and n-3PUFA on myoblast differentiation is not known. The purpose of the study was to identify whether E2 and n-3PUFA possess a synergistic effect on in-vitro myogenesis. Mouse $\mathrm{C} 2 \mathrm{C} 12$ myoblasts, a reliable model to reiterate myogenic events in-vitro, were treated with 10nM E2 and 50 $\mu$ M eicosapentaenoic acid (EPA) independently or combined, for 0-24 h or 0-120 h during differentiation. Immunofluorescence, targeted qPCR and next generation sequencing (NGS) were used to characterize morphological changes and differential expression of key genes involved in the regulation of myogenesis and muscle function pathways. E2 increased estrogen receptor $\alpha(\operatorname{Er} \alpha)$ and the expression of the mitogen-activated protein kinase 11 (Mapk11) within $1 \mathrm{~h}$ of treatment and improved myoblast differentiation and myotube formation. A significant reduction $(p<0.001)$ in myotube formation and in the expression of myogenic regulatory factors Mrfs $(M y o D$, Myog and Myh1) and the myoblast fusion related gene, Tmem $8 c$, was observed in the presence of EPA and the combined E2/EPA treatment. Additionally, EPA treatment at $48 \mathrm{~h}$ of differentiation inhibited the majority of genes associated with the myogenic and striated muscle contraction pathways. In conclusion, EPA and E2 had no synergistic effect on myotube formation in-vitro. Independently, EPA inhibited myoblast differentiation and overrides the stimulatory effect of E2 when used in combination with E2.
\end{abstract}

Keywords: 17 $\beta$-estradiol; n-3PUFA; eicosapentaenoic acid; transcriptome; C2C12; myogenesis

\section{Introduction}

Satellite cells (SCs), the quiescent adult muscle stem cells, are responsible for muscle hypotrophy and regeneration during postnatal development and adulthood [1,2]. For regeneration, activated SCs differentiate into myocytes (fusible myoblasts) and fuse with damaged myofibers [1]. At the cellular level, activation of tissue-specific transcription factors and increased gene abundance prompts the exit of dividing SCs from the cell cycle into the myogenic (myogenesis) pathway [2,3]. Interaction between transcription factors and signal transduction pathways results in the expression of numerous myogenic regulatory factors (Mrfs) that govern the normal progress of myogenesis [2,3].

A reduced number of SCs and an inability to undergo myogenesis may be the outcome of, or contribute to skeletal muscle disorders such as atrophy, cachexia and sarcopenia [4]. In this regard, it has been the aim of many scientists to optimize myogenesis in-vitro to improve therapies to alleviate symptoms associated with muscle atrophy and degeneration. 
The results from several studies suggest that the reproductive hormone estrogen (E2) and n-3 polyunsaturated fatty acids (n-3PUFA) play favorable roles in maintaining skeletal muscle mass and function. For example, postmenopausal women undergoing estrogen-based hormone replacement therapy (HRT) to alleviate the symptoms associated with menopause have greater muscle mass and strength compared to women not undergoing HRT treatment [5-8]. Maintaining muscle function through nutritional strategies has also been an area of intense research [9] with considerable focus on fish oil. Fish oil contains n-3PUFA that are known to improve muscle strength, particularly in older women $[10,11]$. However, while some studies find supportive effects of E2 or n-3PUFA on myoblast differentiation in-vitro [12-16], others have shown an inhibition [17-22].

The cellular mechanism(s) activated by E2 and n-3PUFA regulating myogenesis are equivocal. MAPK/ERK and PI3k/Akt transduction pathways have been both positively and negatively implicated in regulating the transcription, translation and post-translation modifications of Mrfs to support myogenesis following E2 or fatty acid treatment $[13,15,18,23]$. Findings from several studies suggest a positive and synergistic effect of reproductive hormones and fish oil supplements on cardiovascular health of postmenopausal women [24-26]. However, their combined effect on muscle regeneration has not been investigated. In the present study we tested the hypothesis that E2 and n-3PUFA would induce a positive and synergistic effect on myogenesis in-vitro. From the numerous n-3PUFA investigated to date, eicosapentaenoic acid (EPA) has been found to have the most significant effect regulating myogenesis in-vitro $[14,16,17,22]$. Hence, we examined myogenesis fate in mouse $\mathrm{C} 2 \mathrm{C} 12$ myoblasts treated with E2 and EPA independently or in combination, for $0-24 \mathrm{~h}$ or $0-120 \mathrm{~h}$ from induction of differentiation, with a focus on morphological changes and differential expression of key genes involved in muscle differentiation and muscle function pathways.

\section{Results}

\subsection{Morphological Changes and Myoblast Fusion Index}

Morphological changes to C2C12 myoblasts cultured in control-vehicle (Con-Ve), E2, EPA and E2/EPA solutions were determined by immunofluorescence following treatment with anti-Desmin mouse antibody known to be expressed in both myoblasts and myotubes with increased expression as differentiation progresses [27]. When using immunofluorescent analyses, the staining is weak in the cytoplasm of undifferentiated myoblasts and gradually intensifies in elongated myocytes, early tubes and myotubes. Because of its structural distribution with myotube differentiation along the length of a muscle fiber and in close association with the plasma membrane and between myofibrils, Desmin staining defines the tube structure [28-30] making it a valid marker for early and mature myotubes.

In order to confirm the reliability of Desmin as a marker for in-vitro-derived C2C12 myotubes, in a separate experiment we treated the same cultures with Desmin and MYH antibodies at $120 \mathrm{~h}$ of differentiation using two different secondary fluorescent colors and showed that the staining overlapped (Figure 1), confirming that Desmin can be used as a marker for myotube development.

Morphological changes were recorded from the time differentiation was induced ( $0 \mathrm{~h}$ time), up to $120 \mathrm{~h}$ (Figure 2).

The highest number of elongated myoblasts at $48 \mathrm{~h}$ and the highest number of fully formed tubes at $120 \mathrm{~h}$ were both found in E2 treated cultures (Figures 2 and 3). E2 treatment also resulted in the highest fusion index of all conditions and was significantly different compared with EPA and E2/EPA $(p<0.001$, Figure 3). Cells treated with EPA or with E2/EPA had a significantly lower number of initial or mature myotubes $(p<0.01)$ and the lowest fusion index $(p<0.001)$ compared to Con-Ve and E2 treatments, respectively (Figures 2 and 3 ).

The total number of nuclei within microscopic fields increased with time $(p<0.05)$ in all treatment groups with no differences between treatments at any given time point. Collectively, these morphological data indicate that exposure to E2 during myoblast differentiation improves myotube formation in-vitro while EPA and/or the combined E2/EPA treatment repressed formation of myotubes. 


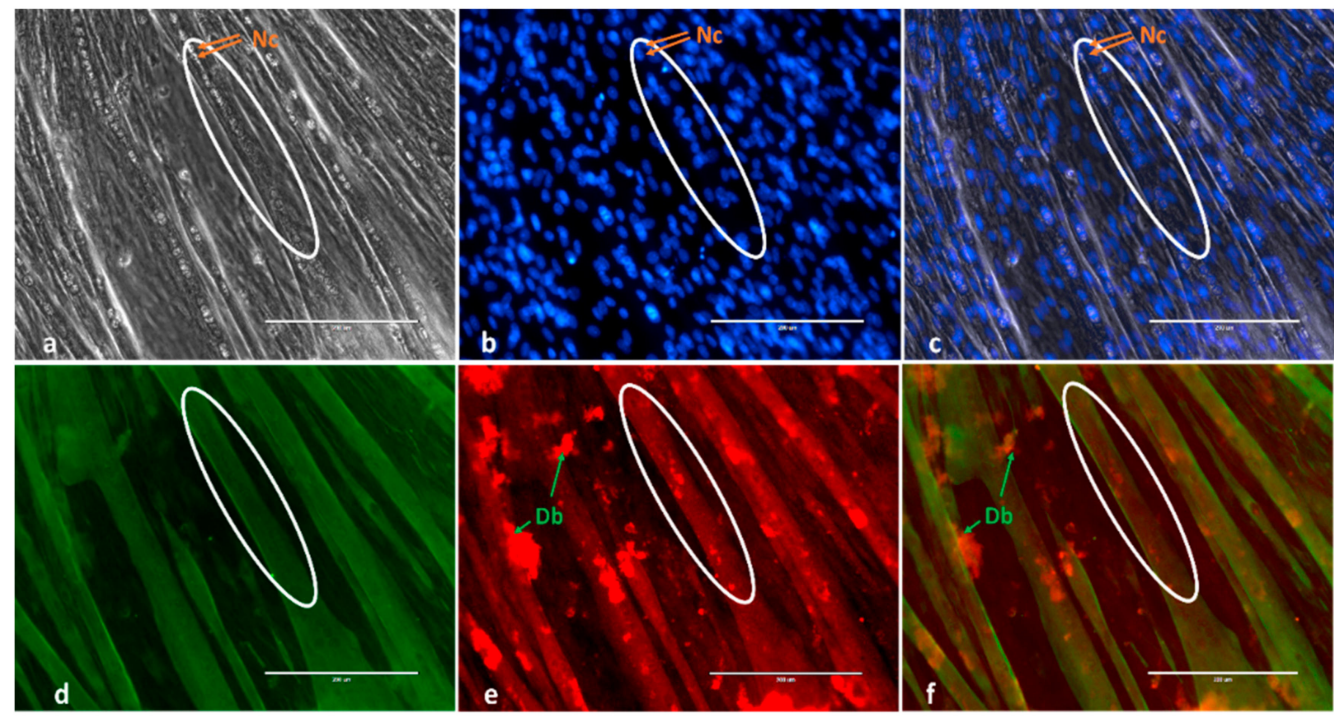

Figure 1. Example of myotube immunofluorescence staining and overlap of Desmin and MYH staining at $120 \mathrm{~h}$ in-vitro derived C2C12 myotubes. (a) Phase-contrast 4',6-diamidino-2-phenylindole (b) (DAPI), blue; (d) Desmin, green; (e) MYH, red; (c) Merged Phase and DAPI and (f) Merged Desmin and MYH. $\mathrm{Nc}$, Nuclei; Db, debris. Images were taken by the EVOSII imaging system (Thermo Fisher) at $\times 20$. Circles mark the same tube presented in phase-contrast and Desmin and MYH markers.

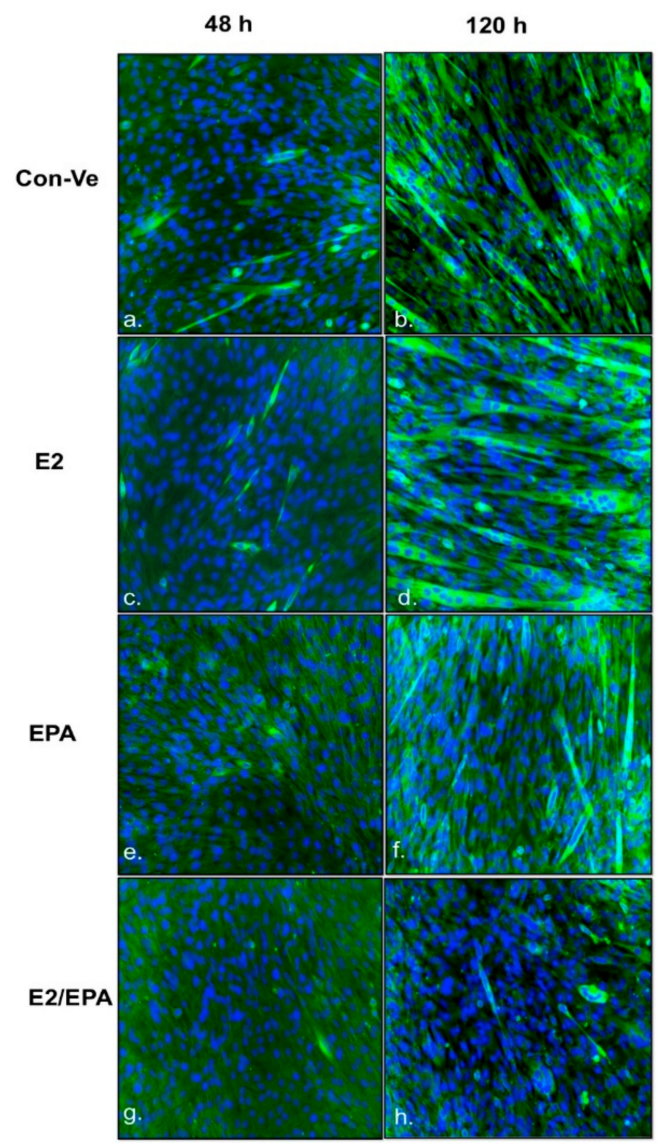

Figure 2. Myotube immunofluorescence staining of $\mathrm{C} 2 \mathrm{C} 12$ treated with control-vehicle (Con-Ve) $(\mathbf{a}, \mathbf{b})$; $17 \beta$-estradiol (E2) (c,d); eicosapentaenoic acid (EPA) (e,f) and E2/EPA (g,h), at 48 and 120 h. Cultures were treated with anti-mouse Desmin followed by GFP secondary antibody (green) and nuclear DAPI (blue) staining. Images were taken by the EVOSII imaging system (Thermo Fisher) at $\times 20$. 

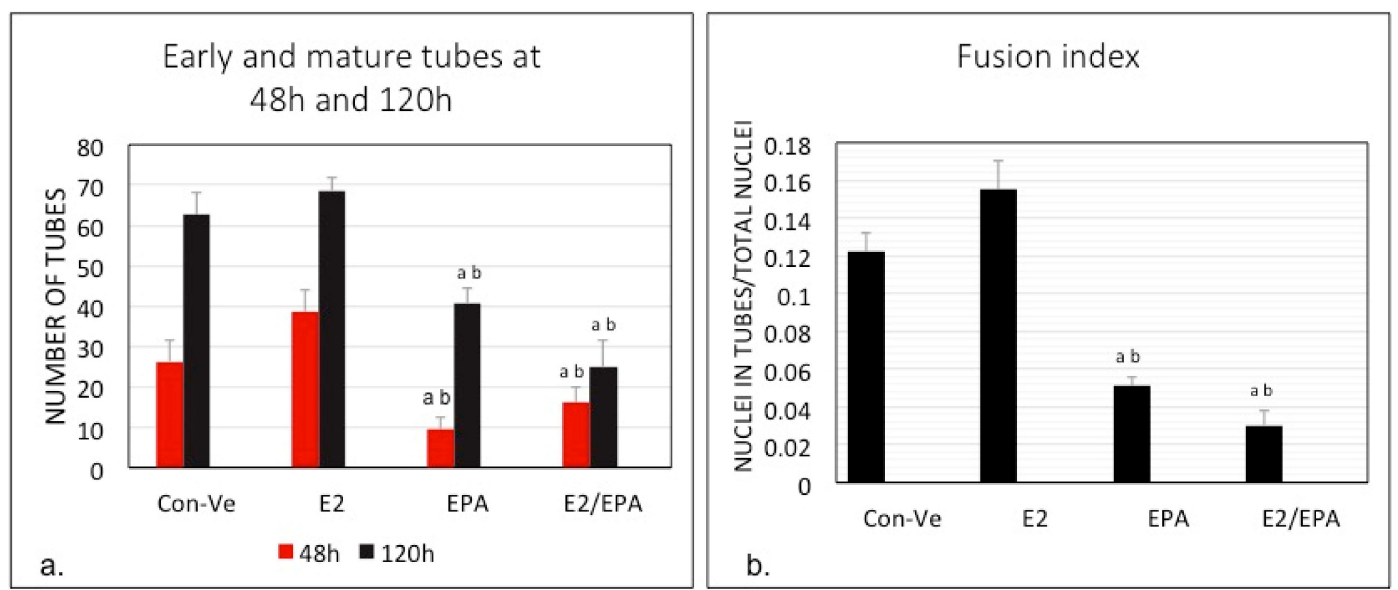

Figure 3. Number of tubes in five microscopic fields at 48 and $120 \mathrm{~h}$ (a) and fusion index (b) following treatment of $\mathrm{C} 2 \mathrm{C} 12$ with Con-Ve, E2, EPA and E2/EPA. Myotube formation and fusion index were higher in E2 treated cells than the other groups. $\left(n=3 ;^{\mathrm{a}} p<0.01 ;{ }^{\mathrm{b}} p<0.001\right.$ between EPA or E2/EPA to control and E2 at the same time point) ( \pm SEM).

\subsection{Gene Expression}

2.2.1. Time-Dependent Expression of Individual Genes Relative to $18 \mathrm{~S}$ Ribosomal RNA Using Real Time qPCR Analysis

Gpr30, Er $\alpha$ and $\operatorname{Er} \beta$

Expression of the three estrogen receptors Gpr30, Er $\alpha$ and $\operatorname{Er} \beta$ at $0-24 \mathrm{~h}$ and $0-120 \mathrm{~h}$ are presented in Figure 4.

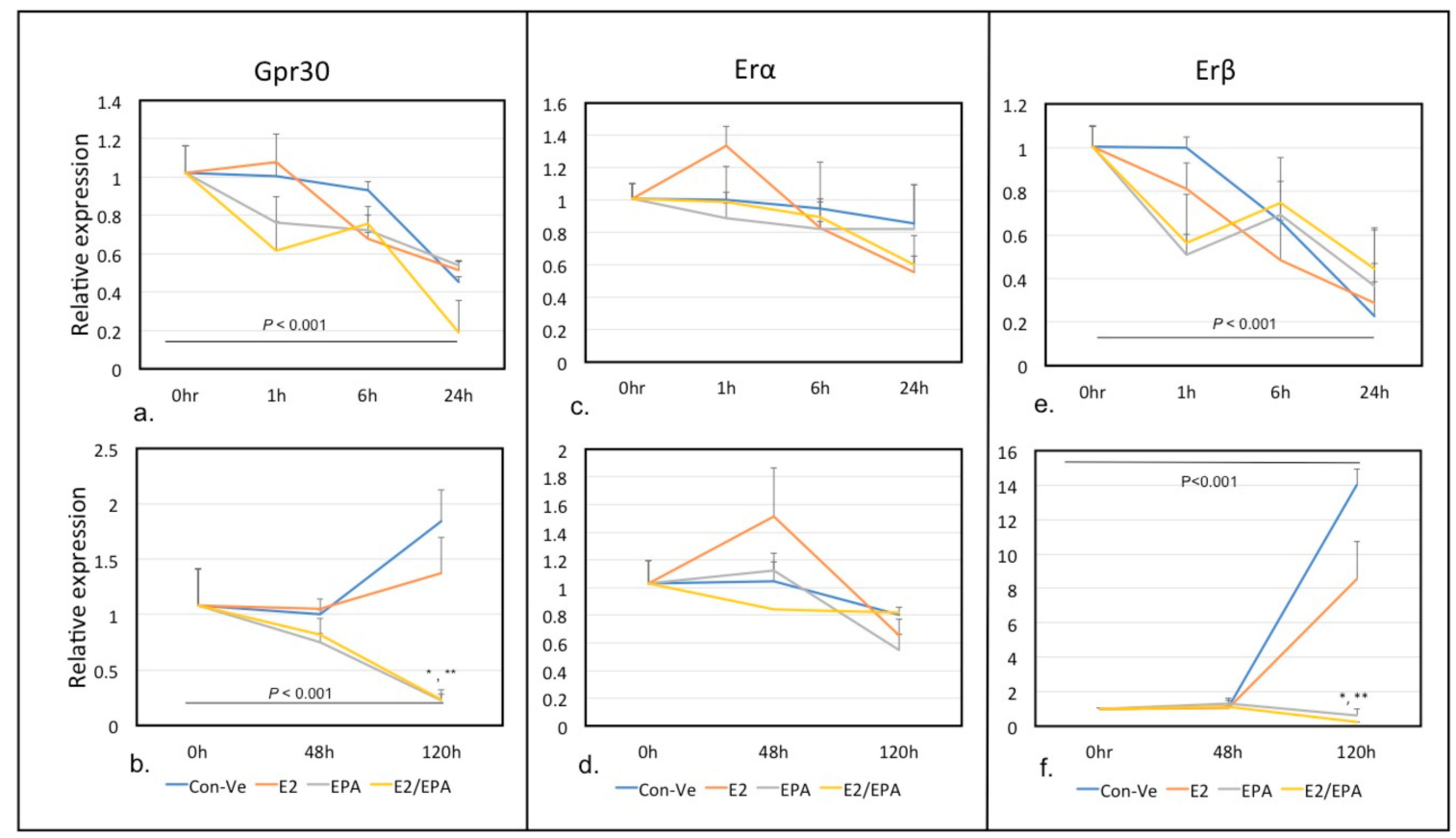

Figure 4. Time-dependent expression of E2 receptors Gpr30, Er $\alpha$ and Er $\beta$. The expression of Gpr30 and Er $\beta$ did not change at $0-24 \mathrm{~h}$ in all groups (a,e). Er $\alpha$ expression peaked at $1 \mathrm{~h}$ only in E2 treated cells followed by a decrease in expression at 6 and $24 \mathrm{~h}$ (c). The expression of $E r \alpha$ remained low for all other time points (d). The expression of Gpr30 and Er $\beta$ increased significantly at $120 \mathrm{~h}$ in both Con-Ve and E2 treated cells $(\mathbf{b}, \mathbf{f}) .\left({ }^{*},{ }^{* *} p<0.001\right.$ compared to Con-Ve at the same time point). ( $\left.{ }^{*} \mathrm{SEM}\right)$. 
Relative expression of Er $\alpha$ peaked at $1 \mathrm{~h}$ (1.33-fold) only in cells treated with E2 followed by a downregulation at 6 and $24 \mathrm{~h}$.

The expression of Gpr30 and Er $\beta$ did not change from 0-24 h. While the expression of Er $\alpha$ stayed low in all treatments at 6 and $120 \mathrm{~h}$, the relative expression of Gpr30 and $\operatorname{Er} \beta$ increased significantly $(p<0.001)$ at $120 \mathrm{~h}$ in both Con-Ve and E2 treated cells, but not in cultures treated with EPA or E2/EPA (Figure 4c-f). Collectively, these results suggest that Er $\alpha$ expression in muscle stem cells is E2 dependent and occurs during early stages of myogenesis. In contrast, both Gpr30's and Erß's expression was independent of $\mathrm{E} 2$ and was associated with fully established myotubes.

Mapk11 and Akt1

Mapk11 expression increased significantly (1.6 fold; $p<0.001)$ at $1 \mathrm{~h}$ only in E2 treated cells (Figure 5a,b). Following this initial increase, Mapk11 expression decreased over time. Akt1 expression did not change throughout the five days of culture for any treatment (Figure $5 c, d$ ).

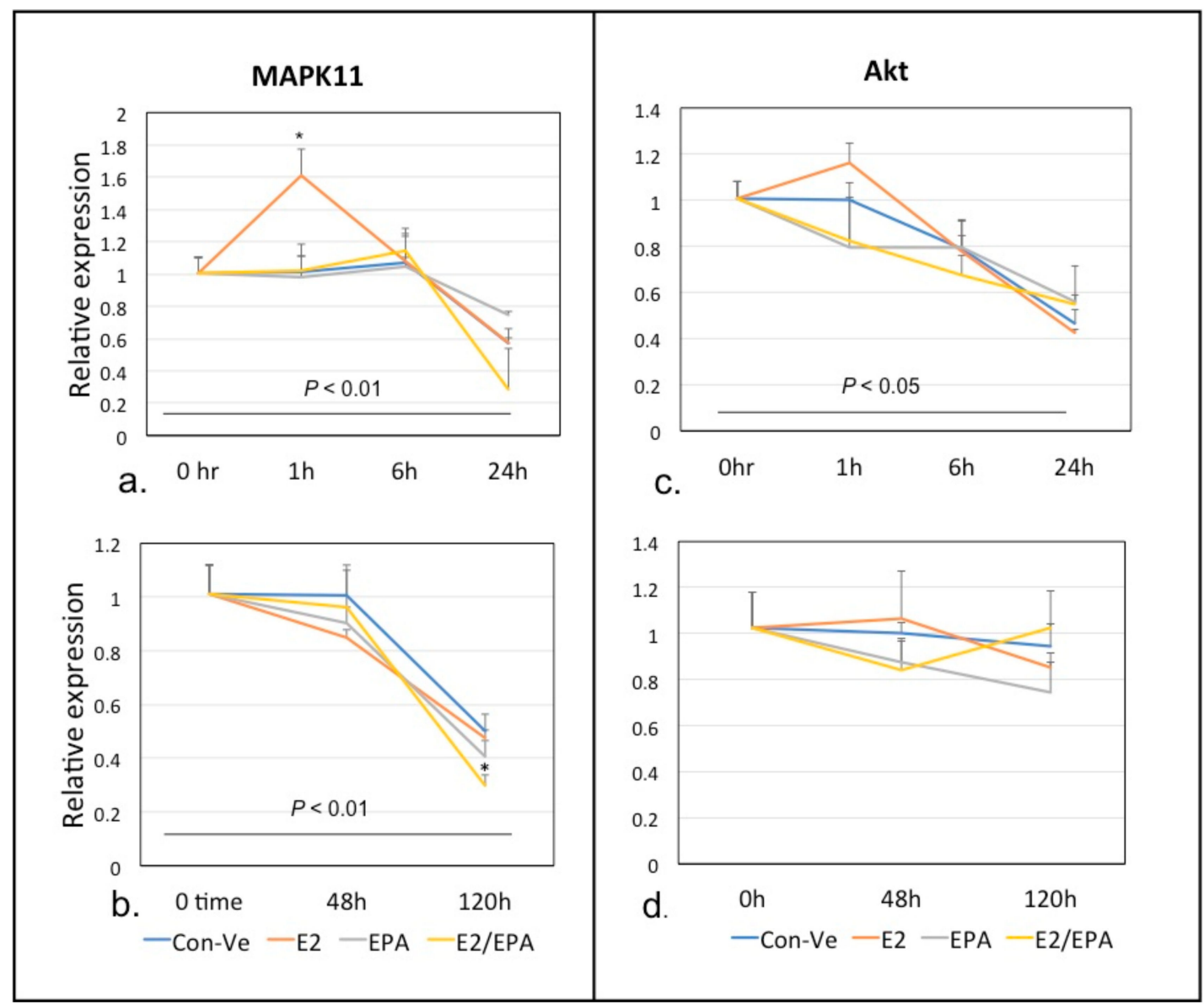

Figure 5. Time-dependent expression of Mapk11 and Akt1 at 0-24 h and 0-120 h. Mapk11 expression peaked at $1 \mathrm{~h}$ only in E2 treated cells followed by a decrease in expression at all other time points $(\mathbf{a}, \mathbf{b})$. The expression of $A k t 1$ was similar in all groups $(\mathbf{c}, \mathbf{d}) .\left({ }^{*} p<0.001\right.$ compared to Con-Ve at the same time point) ( \pm SEM).

\section{MyoD1, Myog, Myh1 and Myomaker (Tmem8c)}

MyoD1 expression decreased over time in all treatments between 0-24 h (Figure 6a; $p<0.001$ ). Expression of MyoD1, Myog and Myh1 increased at $120 \mathrm{~h}$ in Con-Ve and E2 (2-11 folds; $p<0.001)$ but did not change or decreased in EPA and E2/EPA treated cells (Figure $6 \mathrm{~b}-\mathrm{d}$ ). The expression of Tmem $8 \mathrm{c}$ increased over time in both Con-Ve and E2 treated cells ( $p<0.05$ at $48 \mathrm{~h}$ and $p<0.001$ at $120 \mathrm{~h}$ ) but not in EPA or E2/EPA treated cells (Figure 6e). 


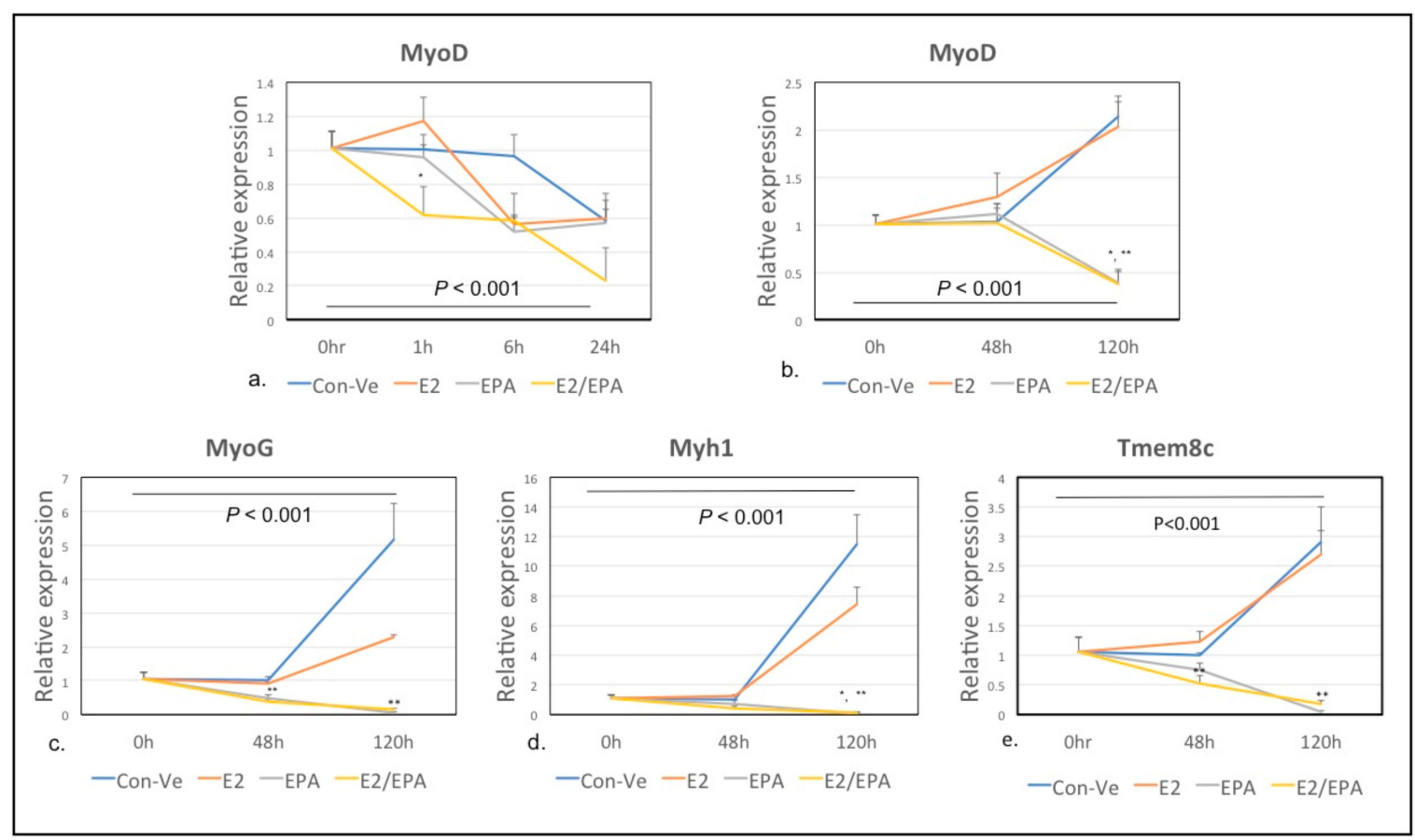

Figure 6. Time-dependent expression of MyoD at 0-24 h and 0-120 h (a,b), myogenin (c), Myh1 (d) and Tmem8c (myomaker, e) at 0-120 h. Myod expression peaked slightly at $1 \mathrm{~h}$ in E2 treated cells. The expression of MyoD, myogenin and Myh1 and Tmem $8 \mathrm{c}$ increased in Con-Ve and E2 treated cells, and at $120 \mathrm{~h}$ of treatment with no change in EPA or E2/EPA treated cells ${ }^{*} p<0.01 ;{ }^{* *} p<0.001$ compared to Con-Ve at the same time point; \pm SEM).

\subsection{Next Generation Sequencing (NGS)}

Differential expression analysis was completed on 12,987 from 26,586 genes identified in the mus musculus database. These genes had $>10$ reads in at least one of the three mRNA samples extracted from each treatment. Heatmaps and glimma plots of differentially expressed genes showed greater similarities between Con-Ve and E2 treated cells than cells treated with EPA (Figure 7).

In EPA treated cells, 6343 and 6248 genes had lower expression than Con-Ve and E2 treated cells, respectively, with $43.2 \%$ and $45.3 \%$ of the genes statistically different between the groups $(p<0.05)$. Totals of 6644 and 6739 genes had higher expression in EPA treated cells than in Con-Ve or E2 treated cells, respectively, with $39.5 \%$ and $42.4 \%$ of the genes statistically different between the groups $(p<0.05)$. A comparison between E2 and Con-Ve treatments showed that although 6491 genes had lower and 6497 had higher expression in E2 treated cells, only $8.9 \%$ and $7.6 \%$ genes were statistically different between the groups $(p<0.05)$, emphasizing similarities between the groups. 


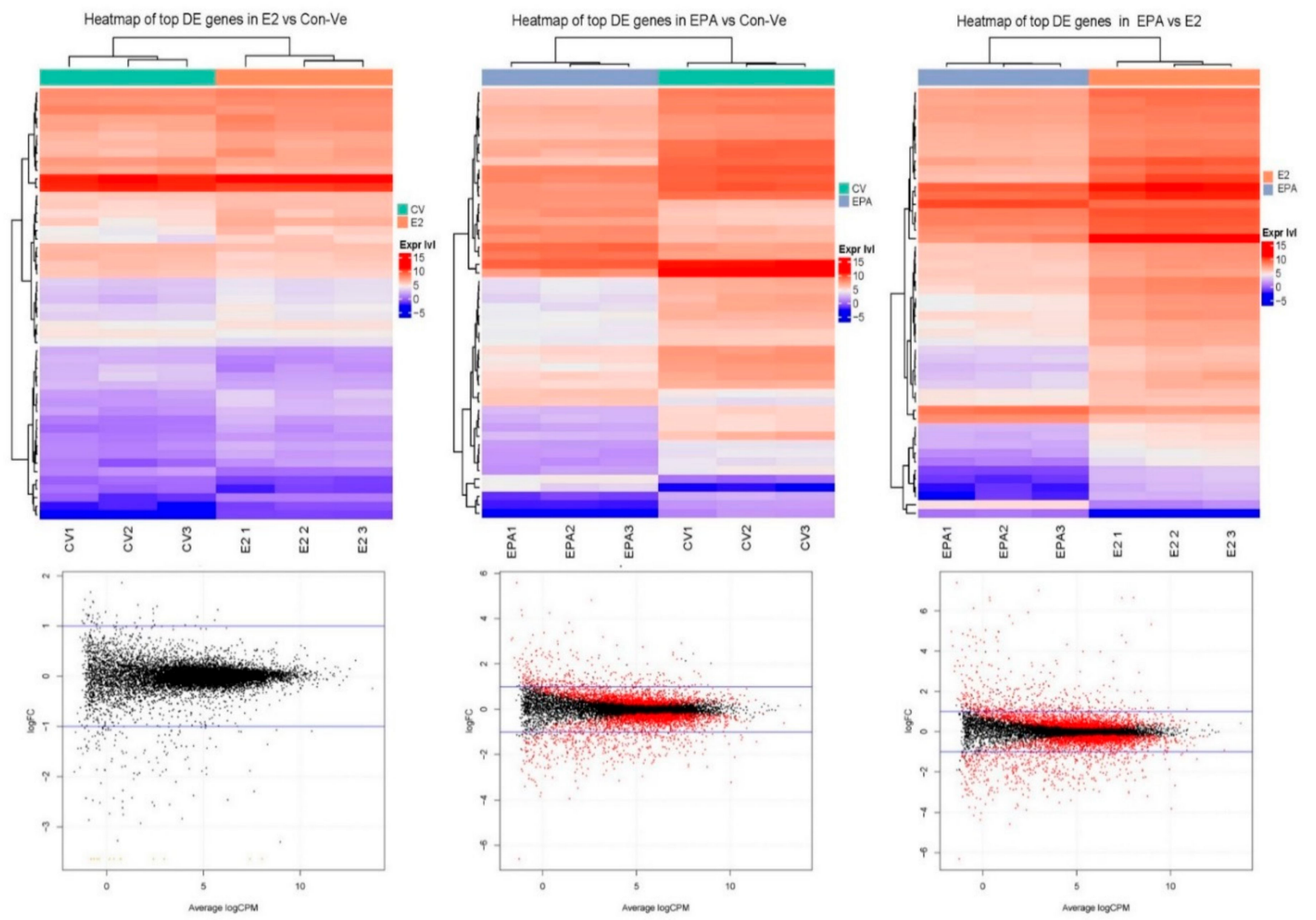

Figure 7. Paired analyses of heatmaps of the top 50 differentially expressed genes (DEG) and glimma plots of genes following Illumina HiSeq 2500 RNA-seq. Differences were greater between E2 and EPA treated cells than with Con-Ve. Con-Ve, green; E2, orange; EPA, light purple. Expression levels are marked from lowest (blue) to highest (red). Red dots in glimma plots represent significant differences $(\geq 0.05)$ in false discovery rate (FDR) values.

2.3.1. Pathway Enrichment Analyses, Gene Ontology and Gene Functional Category in Cultures at $48 \mathrm{~h}$ Treatment with Con-Ve, E2 and EPA

The 10 most significantly enriched pathways in E2 and EPA at $48 \mathrm{~h}$ of treatment when compared to untreated cells or to each other are presented in Figure 8. From these, the striated muscle contraction pathway was the most significantly enriched in E2 treated cells compared to Con-Ve cells (Figure 8a; $p<0.001$ ) or EPA treated cells (Figure 8f; $p<0.001$ ). The pathways enriched in EPA treated cells compared to Con-Ve or E2 treated cells were associated with inflammation and immune responses (Figure 8c; $p<0.003$ ). The RAF/MAPK was also enriched at $48 \mathrm{~h}$ in EPA treated cells compared to Con-Ve cells (Figure 8e; $p<0.001$ ). Gene ontology (GO) and functional category (GFC) analysis showed that genes associated with muscle structure and function had reduced expression in cells treated with EPA (Supplementary Tables S1 and S2). 


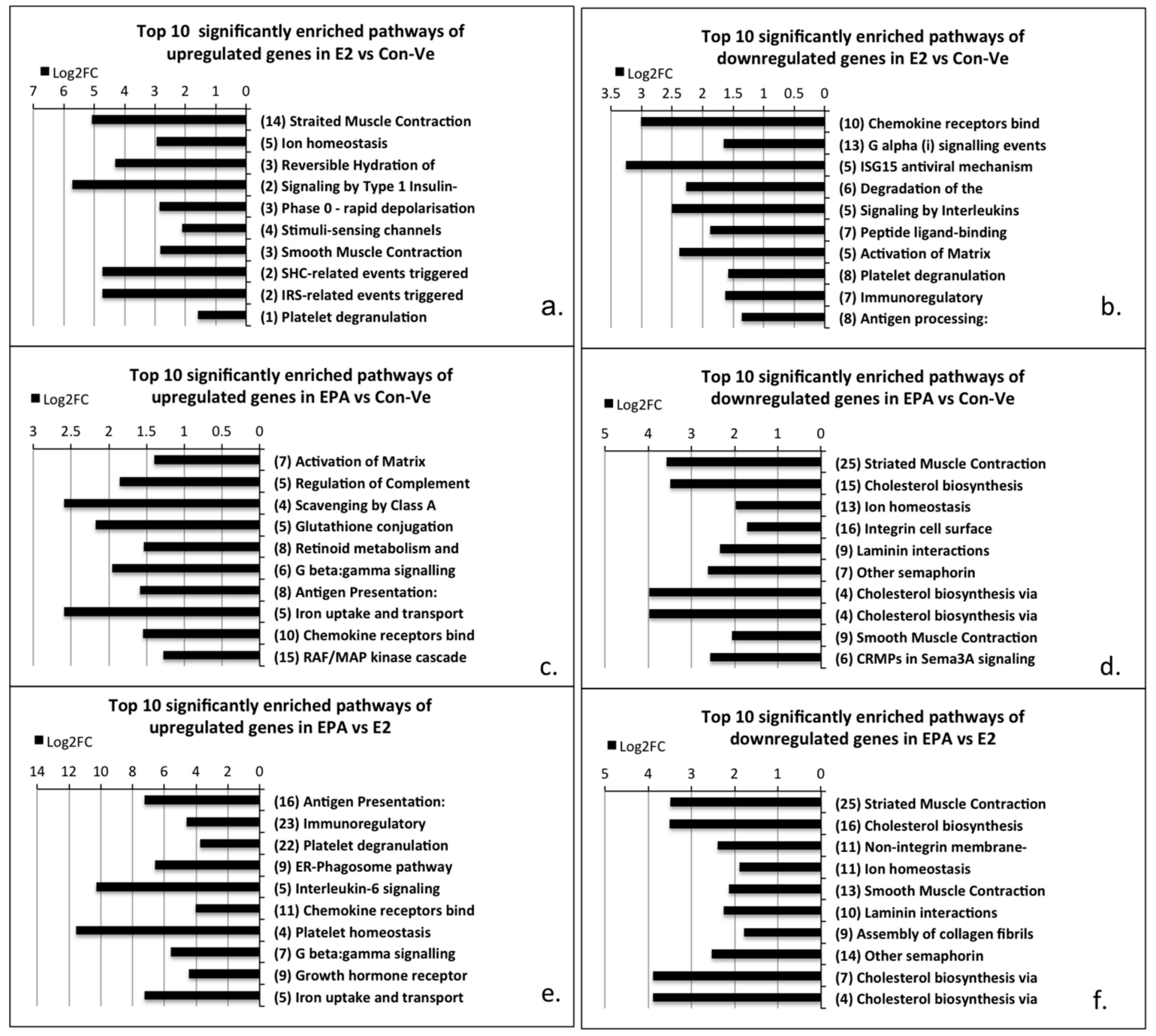

Figure 8. The 10 most significantly enriched pathways for upregulated $(\mathbf{a}, \mathbf{c}, \mathbf{e})$ - and downregulated $(\mathbf{b}, \mathbf{d}, \mathbf{f})$ genes with $\log _{2} \mathrm{FC}>0.5$ comparing E2 vs. Con-Ve (a,b), EPA vs. Con-Ve (c,d) and EPA vs. E2 (e,f). Pathway enrichment analyses were performed using DAVID Bioinformatic (https://david.ncifcrf.gov) followed by identification in Reactome (https://reactome.org).

2.3.2. Gene Expression Profile in the Myogenic and the Striated Muscle Contraction Pathways at $48 \mathrm{~h}$ Treatment with Con-Ve, E2 and EPA

We characterized the myogenic and striated muscle contraction pathways as they are responsible for muscle differentiation, structure and function. From the 24 genes identified in the myogenic pathway, 17 (71\%) had higher expression in E2 treated cells compared with Con-Ve (Figure 9a). From these, Myod1, Cdc42, Cdh2, Mef2c and Myog were statistically different $(p<0.04-0.007)$. Genes significantly repressed by EPA treatment were Mef2a, Mef2c, Mef2d, Myog, TCF12, Cdh15, Cdh2, Cdc42, Spag9, Cdon, Tcf4, Me2, Ctnnal and Myod1 when compared with E2 (Figure 9c; $p<0.01-0.001$ ). The number of reads for Mapk11, Myf5 and Myf6 was significantly higher in EPA treated cells (Figure 9c; $p<0.01-0.001)$. 
a.

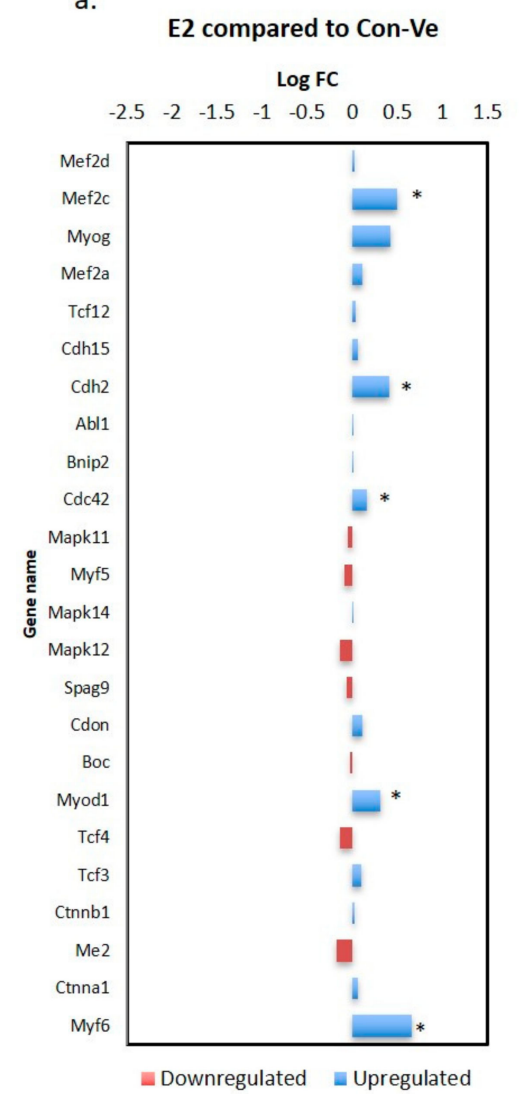

b.

EPA compared to Con-Ve

LogFC

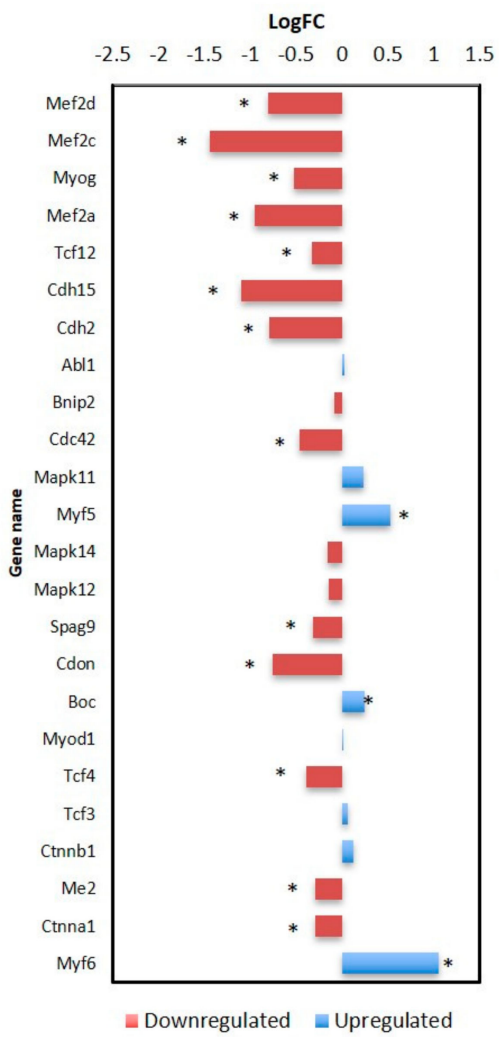

c.

EPA compared to E2

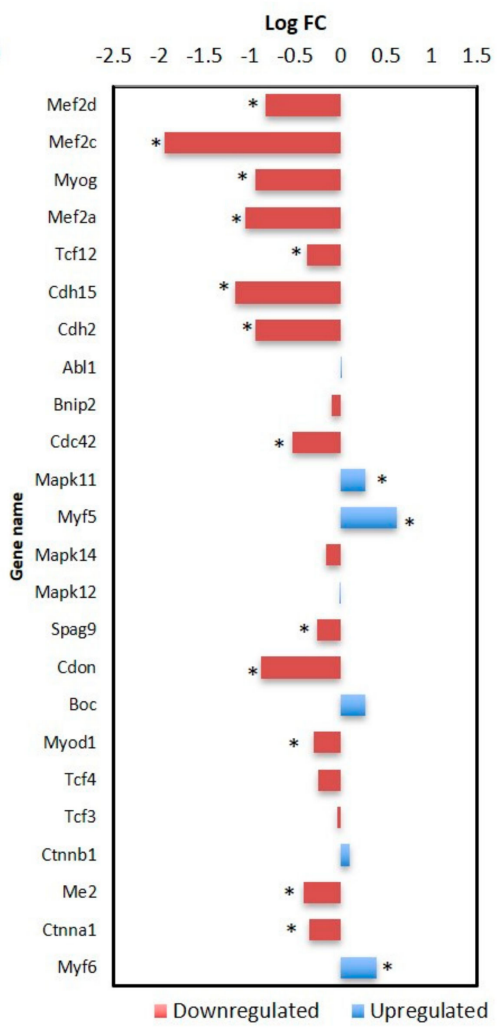

Figure 9. Paired analyses of differentially expressed genes in the myogenic pathway. The majority of the myogenic pathway genes were not differently expressed in E2 treated cells compared to Con-Ve (a). Similar genes in EPA treated cells had significantly lower expression compared to Con-Ve (b) or E2 treated cells (c) ${ }^{*} p<0.05-0.001$ between treatments).

A total of 41 out of $44(93 \%)$ genes within the striated muscle contraction pathway had higher expression in E2 treated cells compared to Con-Ve cells with $20(45 \%)$ significantly different ( $p<0.001-0.05)$ including the myosin heavy chain gene family: Myh1, Myh3, Myh4, Myh6, Myh7 and Myh8. All 44 striated muscle contraction genes had lower expression in EPA than in E2 treated cells with $39(89 \%)$ significantly different $(p<0.001-0.05)$, suggesting overall downregulation of the striated muscle contraction pathway after EPA treatment (Table 1). 
Table 1. Expression profile of striated muscle contraction pathway genes.

\begin{tabular}{|c|c|c|c|c|c|c|c|c|c|c|}
\hline \multicolumn{2}{|r|}{ Gene Name } & \multicolumn{3}{|c|}{ E2 vs. Con-Ve } & \multicolumn{3}{|c|}{ EPA vs. Cont-Ve } & \multicolumn{3}{|c|}{ EPA vs. E2 } \\
\hline & (6) & $\log \mathrm{FC}$ & $p$ Value & FDR & $\log \mathrm{FC}$ & $p$ Value & FDR & $\log F C$ & $p$ Value & FDR \\
\hline Acta1 & actin, alpha 1, skeletal muscle & 0.56 & 0.048 & 0.606 & -2.11 & $1 \times 10^{5}$ & 0.0004 & -2.67 & $1 \times 10^{6}$ & 0.0001 \\
\hline Acta 2 & actin, alpha 2 , smooth muscle, aorta & 0.35 & 0.034 & 0.566 & -0.328 & 0.045 & 0.1138 & -0.68 & 0.0008 & 0.006 \\
\hline Actc1 & actin, alpha, cardiac muscle 1 & 0.66 & 0.024 & 0.551 & -2.53 & $2 \times 10^{6}$ & 0.0001 & -3.19 & $4 \times 10^{7}$ & $4 \times 10^{5}$ \\
\hline Actg1 & actin, gamma, cytoplasmic 1 & -0.02 & 0.831 & 0.985 & -0.49 & 0.0005 & 0.005 & -0.47 & 0.0006 & 0.005 \\
\hline Actn 2 & actinin alpha 2 & 0.92 & 0.001 & 0.364 & -2.29 & $4 \times 10^{6}$ & 0.0002 & -3.22 & $1 \times 10^{7}$ & $2 \times 10^{5}$ \\
\hline Actn3 & actinin alpha 3 & 0.24 & 0.029 & 0.557 & -1.10 & $6 \times 10^{6}$ & $9 \times 10^{5}$ & -1.35 & $1 \times 10^{7}$ & $2 \times 10^{5}$ \\
\hline Actn 4 & actinin alpha 4 & 0.05 & 0.352 & 0.886 & -0.36 & 0.0001 & 0.002 & -0.42 & $3 \times 10^{5}$ & 0.0007 \\
\hline Casq2 & calsequestrin 2 & 0.53 & 0.034 & 0.566 & -2.43 & $1 \times 10^{6}$ & 0.0001 & -2.97 & $2 \times 10^{7}$ & $3 \times 10^{5}$ \\
\hline Des & Desmin & 0.03 & 0.705 & 0.977 & -0.52 & $5 \times 10^{5}$ & 0.001 & -0.55 & $10 \times 10^{3}$ & 0.0007 \\
\hline Jsrp1 & junctional sarcoplasmic reticulum protein 1 & 0.17 & 0.325 & 0.877 & -0.69 & 0.001 & 0.014 & -0.86 & 0.0004 & 0.003 \\
\hline Mybpc1 & myosin binding protein $C$, slow-type & 1.16 & 0.0002 & 0.226 & -1.05 & 0.001 & 0.013 & -2.21 & $3 \times 10^{6}$ & 0.0001 \\
\hline Mybpc2 & myosin binding protein $C$, fast-type & 0.67 & 0.128 & 0.740 & -2.23 & 0.002 & 0.017 & -2.91 & 0.0003 & 0.003 \\
\hline Myh1 & myosin, heavy polypeptide 1 , skeletal muscle, adult & 0.95 & 0.0006 & 0.300 & -2.00 & $2 \times 10^{2}$ & 0.0001 & -2.96 & $9 \times 10^{9}$ & $2 \times 10^{5}$ \\
\hline Myh3 & myosin, heavy polypeptide 3, skeletal muscle, embryonic & 0.60 & 0.016 & 0.529 & -3.21 & $7 \times 10^{8}$ & $3 \times 10^{5}$ & -3.828 & $1 \times 10^{8}$ & $1 \times 10^{5}$ \\
\hline Myh4 & myosin, heavy polypeptide 4 , skeletal muscle & 0.99 & $6 \times 10^{5}$ & 0.183 & -0.55 & 0.005 & 0.029 & -1.55 & $1 \times 10^{6}$ & 0.0001 \\
\hline Myh6 & myosin, heavy polypeptide 6, cardiac muscle, alpha & 1.10 & 0.0001 & 0.183 & -1.69 & $2 \times 10^{5}$ & 0.0008 & -2.79 & $2 \times 10^{7}$ & $3 \times 10^{5}$ \\
\hline Myh7 & myosin, heavy polypeptide 7, cardiac muscle, beta & 0.93 & 0.0004 & 0.262 & -1.34 & 0.0005 & 0.006 & -2.15 & $8 \times 10^{6}$ & 0.0002 \\
\hline Myh8 & myosin, heavy polypeptide 8 , skeletal muscle, perinatal & 1.18 & 0.0006 & 0.295 & -2.21 & $1 \times 10^{5}$ & 0.0004 & -3.39 & $2 \times 10^{7}$ & $3 \times 10^{5}$ \\
\hline Myl1 & myosin, light polypeptide 1 & 0.50 & 0.035 & 0.566 & -0.83 & 0.002 & 0.016 & -1.34 & $8 \times 10^{5}$ & 0.001 \\
\hline Myl4 & myosin, light polypeptide 4 & 0.61 & 0.047 & 0.604 & -1.74 & 0.0001 & 0.002 & -2.36 & $1 \times 10^{5}$ & 0.0003 \\
\hline Myl9 & myosin, light polypeptide 9 , regulatory & 0.09 & 0.661 & 0.971 & -0.90 & 0.002 & 0.016 & -1.00 & 0.001 & 0.008 \\
\hline Myom1 & myomesin 1 & 0.52 & 0.021 & 0.539 & -2.00 & $2 \times 10^{6}$ & 0.0001 & -2.52 & $3 \times 10^{7}$ & $4 \times 10^{5}$ \\
\hline Myom 2 & myomesin 2 & 0.17 & 0.138 & 0.754 & -0.86 & $1 \times 10^{5}$ & 0.0005 & -1.03 & $2 \times 10^{6}$ & 0.0001 \\
\hline $\mathrm{Neb}$ & Nebulin & 0.40 & 0.036 & 0.566 & -2.02 & $4 \times 10^{7}$ & $8 \times 10^{5}$ & -2.42 & $9 \times 10^{8}$ & $2 \times 10^{5}$ \\
\hline Smpx & small muscle protein, $X$-linked & 0.49 & 0.047 & 0.604 & -1.67 & $4 \times 10^{5}$ & 0.001 & -2.16 & $4 \times 10^{6}$ & 0.0002 \\
\hline Tcap & titin-cap & 0.87 & 0.031 & 0.561 & -0.59 & 0.169 & 0.285 & -1.47 & 0.003 & 0.015 \\
\hline Tmod1 & tropomodulin 1 & 0.54 & 0.008 & 0.482 & -0.84 & 0.0005 & 0.005 & -1.38 & $1 \times 10^{5}$ & 0.0003 \\
\hline Tnnc1 & troponin $C$, cardiac/slow skeletal & 0.51 & 0.060 & 0.624 & -1.43 & 0.0002 & 0.003 & -1.94 & $1 \times 10^{5}$ & 0.0004 \\
\hline Tnnc2 & troponin $C 2$, fast & 0.51 & 0.072 & 0.646 & -1.72 & $7 \times 10^{5}$ & 0.001 & -2.23 & $9 \times 10^{6}$ & 0.0003 \\
\hline Tnni1 & troponin I, skeletal, slow 1 & 0.49 & 0.068 & 0.639 & -1.90 & $2 \times 10^{5}$ & 0.0007 & -2.40 & $3 \times 10^{6}$ & 0.0001 \\
\hline Tnni2 & troponin I, skeletal, fast 2 & 0.39 & 0.187 & 0.800 & -1.65 & 0.0001 & 0.003 & -2.05 & $3 \times 10^{5}$ & 0.0007 \\
\hline Tnni3 & troponin I, cardiac 3 & 0.27 & 0.457 & 0.918 & -0.90 & 0.05 & 0.129 & -1.18 & 0.015 & 0.050 \\
\hline Tnnt1 & troponin $T 1$, skeletal, slow & 0.32 & 0.146 & 0.764 & -1.31 & 0.0001 & 0.002 & -1.64 & $1 \times 10^{5}$ & 0.0004 \\
\hline Tnnt2 & troponin $T 2$, cardiac & 0.29 & 0.268 & 0.855 & -1.97 & $2 \times 10^{5}$ & 0.0007 & -2.27 & $7 \times 10^{6}$ & 0.0002 \\
\hline Tnnt3 & troponin $\mathrm{T} 3$, skeletal, fast & 0.39 & 0.152 & 0.769 & -1.63 & 0.0001 & 0.001 & -2.025 & $1 \times 10^{5}$ & 0.0004 \\
\hline Tpm1 & tropomyosin 1 , alpha & 0.13 & 0.139 & 0.756 & -0.36 & 0.001 & 0.009 & -0.49 & 0.0001 & 0.001 \\
\hline Tpm2 & tropomyosin 2 , beta & 0.33 & 0.061 & 0.629 & -0.68 & 0.001 & 0.012 & -1.02 & $8 \times 10^{5}$ & 0.001 \\
\hline Tpm3 & tropomyosin 3, gamma & -0.09 & 0.342 & 0.885 & -0.42 & 0.001 & 0.009 & -0.33 & 0.005 & 0.023 \\
\hline Tpm4 & tropomyosin 4 & -0.08 & 0.299 & 0.868 & -0.14 & 0.072 & 0.157 & -0.06 & 0.38 & 0.506 \\
\hline Ttn & titin & 0.19 & 0.152 & 0.769 & -1.17 & $4 \times 10^{6}$ & 0.0002 & -1.37 & $1 \times 10^{6}$ & 7E-05 \\
\hline $\operatorname{Vim}$ & vimetin & 0.09 & 0.419 & 0.904 & -0.03 & 0.728 & 0.810 & -0.13 & 0.258 & 0.381 \\
\hline
\end{tabular}




\subsubsection{Genes Unique to E2 and EPA Treated Cells}

We identified genes uniquely expressed in E2 and in EPA treated cells (Supplementary Tables S3 and S4). Genes of interest from the genes expressed in E2 and not in EPA treated cells were: fibromodulin (Fmod), known to regulate myoblast differentiation by controlling calcium influx into the cells [31]; fibroblast growth factor binding protein 1 ( $F g f b p 1)$, secreted by muscle tissue to slow age-related degeneration [32]; Shisa family member 2 (Shisa2), known to participate in myoblast fusion [33], fox-1 homolog (Rbfox1), known to promote the transcription factor myocyte enhancer factor 2D (Mef2D) splicing and subsequent myogenesis [34] and Mef2D itself.

Genes unique to EPA treated cells were mostly associated with immune response. Other genes in this list included: orosomucoid 1 (orm1), known to increase muscle glycogen [35]; endothelial PAS domain protein 1 (Epas1), known to promote adipose differentiation [36]; and lipocalin 2 (Lcn2), which regulates muscle regeneration [37]. Of interest is also haptoglobin $(\mathrm{Hp})$, known to regulate adipose tissue development and fat metabolism [38]; and interleukin 6 (Il6), known to promote muscle differentiation and hypertrophy except when prolonged high doses are used $[39,40]$.

\section{Discussion}

Several studies have reported that E2 and n3-PUFA, independently, have a positive effect on muscle function particularly in older women, and have stimulatory effects on myotube formation in-vitro. However, their combined effect on muscle regeneration in-vivo or in-vitro is unknown. Our study is the first to report that E2 and EPA induce divergent outcomes on myoblast differentiation, and that they have no synergistic effect when used in combination. Sequential imaging over five days of treatment with $10 \mathrm{nM} \mathrm{E2}$, a commonly used concentration, increased myotube number and fusion index. However, both significantly decreased when cells were treated with a concentration of $50 \mu \mathrm{M}$ EPA alone or combined with $10 \mathrm{nM}$ E2 (Figure 3).

The present study focused on gene expression analyzed by qPCR and NGS, and while protein expression would have provided additional information regarding post-transcriptional changes, the morphological changes necessary for myoblast commitment to the myogenic lineage and their progress in myogenesis, are largely dependent on a complex network of genes [1,2]. We show that EPA interferes with this network by repressing or maintaining expression of specific genes typically regulated during differentiation, resulting in an attenuated myogenic pathway (Figure 9). For example, the reduced expression of MyoD1 and Myog and increased expression of Myf6 (also known as Mrf4) and Myf5 in cells treated with EPA for $48 \mathrm{~h}$ suggests a lack of cellular commitment to the myogenic lineage (Figure 9) [2]. Mapk11 was also expressed higher in these cells compared to Con-Ve or E2 treated cells (Figure 8). Mapk11 supports myoblast proliferation and initiation of myogenesis and has been shown to be downregulated after activating MyoD and MEF2C in committed myoblasts [41,42]. Even if EPA treated cells were committed to the myogenic lineage, they had limited ability to fuse with each other to form tubes as EPA repressed the expression of Tmem8c (Figure 6) and Sisha 2 (Table S3), which are essential for myoblasts' membrane fusion and myotube extension $[33,43]$. EPA treatment also repressed the expression of genes associated with muscle function such as the Myh gene family, linked to muscle fiber type and substrate metabolism (Table 1) [44].

E2 activates cellular pathways via its intracellular receptors, $\operatorname{Er} \alpha$ and $\operatorname{Er} \beta$, resulting in the receptors' translocation to the nucleus to act as transcription factors that regulate E2-dependent gene expression [45]. E2 also interacts with a membrane G-protein coupled receptor 30 (GPR30) [32]. Both the intracellular and membrane receptors have been associated with in-vitro myoblast differentiation through signal transduction pathways [13,23,46]. Elevated expression of $\operatorname{Er} \beta$ and Gpr30 was independent of E2 treatment and was limited to cultures with fully formed myotubes in both Con-Ve and E2 treated cells. While the precise role of Er $\beta$ in fully formed myotubes is unknown, an increase in GPR30 during late myogenesis is attributed to its protective role from oxidative stress through activation of creatine kinase [46]. We observed a 1.3-fold increase in Er $\alpha$ expression at $1 \mathrm{~h}$ only in E2 treated cells followed by a downregulation. Although statistically not different to the Con-Ve 
group, we speculate that this peak in Era expression is of biologically relevance and is E2 dependent. Ronda et al. [47] showed that the use of an antagonist of ERs and specific siRNAs to block Er $\alpha$ and Er $\beta$ expression resulted in $\operatorname{Er} \alpha$, but not $\operatorname{Er} \beta$, mediating ERK2 activation by $17 \beta$-estradiol.

Our findings show that Mapk11, and not $A k t 1$, is the primary target to differentiation stimuli by E2. While $A k t 1$ expression remained unchanged through differentiation for all treatment groups, we observed a significant increase in the expression of Mapk11 at $1 \mathrm{~h}$ with E2 treatment, supporting previous suggestions of regulation by the MAPK transduction cascade (Figure 5) $[13,15,23,48]$. The increase in Mapk11 expression also coincided with an increase Er $\alpha$ expression, suggesting that the regulation of myogenesis through activation of the MAPK transduction pathway may be via this E2 receptor.

Cotreatment of $\mathrm{C} 2 \mathrm{C} 12$ cells with $\mathrm{E} 2$ was insufficient to suppress EPA's negative effect on myogenesis. This dominant effect of EPA has been reported in previous work on E2-dependent tumours where n-3PUFA prevented cell proliferation by altering lipid composition of the plasma membrane and subsequently interfered with E2-dependent signaling cascades such as the MAPK/Erk pathway [49]. Moreover, higher n-3PUFA to E2 ratios were shown to have a greater inhibitory effect on tumour cell proliferation [49]. Thus, the inability of E2 to overturn EPA's inhibitory effect in the present study may be related to the high EPA to E2 ratio (5000:1).

Our finding that n-3PUFA (i.e., EPA) inhibits myogenesis is in agreement with accumulating evidence showing the negative effect of n-3PUFA on myotube formation in-vitro $[17,19,22]$. These studies highlight the potential negative effects of n-3PUFA consumption during pregnancy when de novo myogenesis is initiated at the embryonic and neonatal stages because disruption to myogenesis at this time may lead to postnatal muscle deficiencies in mass and function [50]. However, the n-3PUFA to $\mathrm{E} 2$ ratio is reduced considerably during pregnancy, thus preventing any proposed inhibitory effect of n-3PUFA on muscle development in-utero. It is estimated that levels of circulating E2 are nearly 100 times higher [51,52] while n-3PUFA in the blood are approximately 10 times lower [53] during pregnancy. Indeed, n-3PUFA ingestion has been associated with positive effects on newborn visual and cognitive development [54] and had no detrimental effects on postnatal development or in follow-up years after birth [55].

In contrast to our original research hypothesis, cotreatment of E2 and n-3PUFA did not have a synergistic effect on in-vitro myogenesis, raising the possibility that dietary supplements of fish oil (i.e., n-3PUFA) may interfere with the positive affect estrogen has on muscle regeneration in women on HRT. Recently, Ghnaimawi et al. [17] showed that treatment of differentiating C2C12 myoblasts with 50 $\mu \mathrm{M}$ EPA and DHA for four days increased adipogenesis and inflammatory-related genes and reduced tube formation. We did not examine adipose cell formation in our cultures following treatment with EPA, but were able to identify that IL6 and adipose tissue related genes were uniquely expressed in cells treated with EPA (Tables S3 and S4). High doses of n-3PUFA intake have shown to increase the expression of uterine Il6 [56].

In the present study we characterized morphological and molecular changes of myoblasts treated with E2 and EPA independently or combined. EPA significantly impaired the expression of muscle differentiation genes and genes associated with muscle function within $48 \mathrm{~h}$ of treatment. In contrast, E2 improved myoblast fusion and myotube formation and enhanced the expression of genes within the striated muscle contraction pathway. This indicates that reproductive hormone can be used to stimulate myoblast entry into the myogenic pathway for therapeutic purposes.

Further investigation is required to explore if n-3PUFA ingestion will increase intramuscular adipose tissue and whether ingestion while under HRT may override the positive effect E2 has on skeletal muscle. Further studies are also required to identify the optimal E2 to n-3PUFA ratio when consumed together in order to maximize the beneficial effect on general wellbeing with no harmful effect on muscle health. 


\section{Materials and Methods}

\subsection{Cell Culture}

C2C12 murine myoblasts at passage 7-9 [57] (LONZA, Sydney, Australia) were cultured in proliferation medium composed of $4.5 \mathrm{~g} / \mathrm{L}$ glucose Dulbecco's modified eagle medium (DMEM; Life Technologies, Melbourne, Australia) supplemented with 10\% fetal bovine serum (FBS; Sigma, Melbourne, Australia) and 0.2\% penicillin/streptomycin (PenStrep; Life Technologies). Cells were plated onto $1 \%$ Geltrex (Life Technologies) coated 96-well dishes in proliferation medium at a density of 30,000 cells/mL (6000 cells/well). Culture dishes were maintained at $37{ }^{\circ} \mathrm{C}$ in a humidified incubator at $5 \% \mathrm{CO}_{2}$ /air mixture for $48 \mathrm{~h}$ to reach $80 \%-90 \%$ confluence. At $80 \%-90 \%$ confluence, proliferation medium was replaced with differentiation medium $(4.5 \mathrm{~g} / \mathrm{L}$ glucose DMEM and 0.2\% Pen/Strep) containing 2\% horse serum (HS; Sigma).

\subsection{E2 and EPA Treatments}

EPA and E2 were purchased from Sigma-Merck (Sydney, Australia). The company has certified EPA's $13 C$ NMR identity conformed to structure. EPA was used within six months of purchase. Frozen $\left(-80{ }^{\circ} \mathrm{C}\right)$ stock solutions of $10 \mathrm{M} \mathrm{E} 2$ and $100 \mathrm{mM}$ EPA (Sigma) in 100\% ethanol were diluted into concentrations of $100 \mu \mathrm{M}$ and $20 \mathrm{nM}$, respectively. Solutions were placed in a $56{ }^{\circ} \mathrm{C}$ water bath until EPA was dissolved, followed by further 1-2 $\mathrm{h}$ incubation at room temperature to allow EPA/BSA and E2/BSA conjugation. Solutions were then diluted in $4.5 \mathrm{~g} / \mathrm{L} \mathrm{DMEM}$ containing $2 \% \mathrm{HS}$ to a final working concentration of $50 \mu \mathrm{M}$ EPA and $10 \mathrm{nM}$ E2. These concentrations were chosen based on previously published reports $[13,22,58]$. A control-vehicle (Con-Ve) solution contained the same proportion of $2 \%$ bovine serum albumin (BSA), $2 \%$ horse serum (HS) and ethanol (0.1\%) and was handled like the treatment groups.

\subsection{Immunofluorescence, Mytube Formation and Fusion Parameters}

In an independent experiment we have shown Desmin to overlap with MYH expression in in-vitro derived C2C12 myotubes at $120 \mathrm{~h}$ of differentiation (Figure 1). For this, confluent cells (80-90\%) were cultured in Con-Ve for 120 h. At 120 h, cultures were washed, fixed and analyzed by immunofluorescence as previously described [29,59]. Fixed cultures were stained with the appropriate secondary antibodies (Alexa Fluor 488; green and 594; red, Life Technologies) and costained with 4',6-diamidino-2-phenylindole (DAPI) (Life Technologies) following an overnight incubation with anti-mouse Desmin (Life Technologies) and anti-mouse skeletal muscle myosin heavy chain antibody (Life Technologies). For the time-dependent development studies, cultures were treated only with anti-Desmin followed by the appropriate secondary antibody. At 0,48 and $120 \mathrm{~h}$, cultures were washed, fixed and analysed by immunofluorescence as before.

Stained cultures were visualised under the EVOS-II imaging system using the appropriate fluorescent filters. Pictographs were taken under 20× magnification with five image fields (one in the centre of the well and four others around the centre) from each treatment at 0 (myoblasts before differentiation), 48 (elongating myoblasts and myocytes and initiation of mytubes) and $120 \mathrm{~h}$ (fully formed myotubes; Figure 1). The number of elongated Desmin-positive myoblasts with $\geq 1$ DAPI stained nucleus was recorded at $48 \mathrm{~h}$. At $120 \mathrm{~h}$, the number of Desmin-positive myotubes containing $\geq 2$ DAPI stained nuclei, the total number of DAPI stained nuclei within the field and the total number of DAPI stained nuclei within tubes were all recorded. Fusion index was calculated as the proportion of nuclei within tubes from the total number of nuclei in the field. 


\subsection{Transcriptome Analyses}

\subsubsection{RNA Extraction}

Total RNA was extracted from cells using the PureLink RNA Mini Kit (Qiagen, Melbourne, Australia) following manufacturer's instructions and stored at $-80^{\circ} \mathrm{C}$ until used for sequencing and target qPCR analyses.

\subsubsection{Real Time Quantitative PCR}

Taqman-FAM-labelled primer/probes for the different genes cDNA was synthesized by using oligo (dT)20, and SuperScript ${ }^{\mathrm{TM}}$ III Reverse Transcriptase (Life Technologies, Australia) according to the manufacturers' instructions. Time-dependent qPCR of differential expression was used to identify hierarchy of gene expression activated by E2 or by EPA treatment. We examined expression of the E2 receptors alpha and beta (Er $\alpha$ : Esrra Mm00433143_ml, Er $\beta$ : Esrrb Mm00442411_ml) and G protein-coupled estrogen receptor-30 (Gpr30 Mm02620446_ml), known to initiate transduction cascades involved in myogenesis; the downstream target genes of these receptors, mitogen-activated protein kinase 11 (Mapk11 Mm004440955_ml) and serine/threonine kinase 1 (Akt1 Mm00437443_ml), known to activate Mrfs' transcription and post-translation modification; the Mrf genes, myoblast determination protein (MyoD Mm00440387_ml), myogenin (Myog Mm00446194_ml), myosin heavy chain 1 (Myh1 Mm01332489_ml); and the mouse myoblast fusion gene, myomaker (Tmem8c Mm00481256_ml), involved in myoblast fusion, myotube extension and myotube maturation.

Expressions of Er $\alpha, E r \beta, G p r 30$, Mapk11, Akt1 and MyoD were measured at $0,1,6$ and $24 \mathrm{~h}$ from initiation of differentiation. In a separate experiment, the expression of $\operatorname{Er\alpha }, \operatorname{Er} \beta, G p r 30, M a p k 11, A k t 1$, MyoD and Myog, Myh1 and Tmem $8 \mathrm{c}$ was examined at 0, 48 and $120 \mathrm{~h}$. $18 \mathrm{~S}$ ribosomal RNA (Rn18s Mm03928990_ml) was used as housekeeping gene for the early and late gene expression experiments.

RT-qPCR samples were mixed with Taqman probes in a final reaction volume of $20 \mu \mathrm{L}$. PCR protocol included $2 \mathrm{~min}$ at $50^{\circ} \mathrm{C}$ for UNG activation, $10 \mathrm{~min}$ at $95^{\circ} \mathrm{C}$ followed by 40 cycles of $95^{\circ} \mathrm{C}$ for $15 \mathrm{~s}$ and $60^{\circ} \mathrm{C}$ for $60 \mathrm{~s}$. Relative amounts of mRNAs to Rn18s were calculated as $\Delta \Delta \mathrm{CT}$ from three independent repeats with duplicates (total $n=6$ ).

\subsubsection{Next Generation Sequencing (NGS) Using Illumina HiSeq 2500 RNA-seq}

Differential gene expression was performed on mRNA extracted from Con-Ve, $10 \mathrm{nM}$ E2 or 50 $\mu \mathrm{M}$ EPA treated cells at $48 \mathrm{~h}$ of differentiation. Transcripts were quantified, normalized and aligned against the Mus musculus genome database. The number of reads that were mapped to each known gene was summarized. A differential expression of genes (DEG) was used with "edgeR" (in R 3.5.0) to generate $\log _{2} \mathrm{FC}$ (fold change) and significant differences $(<0.05)$ represented by $\mathrm{P}$ and false discovery rate (FDR) for paired analyses of E2 vs. Con-Ve, EPA vs. Con-Ve and EPA vs. E2.

Gene ontology (GO) and gene functional category (GFC) analyses of upregulated and downregulated genes with $\log _{2}$ FC $>0.5$ were performed using DAVID Bioinformatic (https://david. ncifcrf.gov) [60] followed by Pathway Enrichment (PE) analyses in Reactome (https://reactome.org) [61].

\subsection{Statistical Analyses}

All analyses within the study contained a total of three repeats with two replicates for each of the treatment groups (total $n=6$ ). One- and two-way ANOVA were used to identify statistical differences associated with time and treatment, with $p<0.05$ indicating significant differences for cell number, tube formation, fusion index and gene expression using the Holm-Sidak as post hoc test.

Supplementary Materials: The following are available online at http://www.mdpi.com/1422-0067/21/3/745/s1.

Author Contributions: Conceptualization, O.L.-K.; Methodology, O.L.-K. and D.M.C.; Investigation, O.L.-K. and D.M.C.; Resources, O.L.-K. and J.A.H.; Data Curation, O.L.-K., D.M.C. and J.A.H.; Writing-Original Draft 
Preparation, O.L.-K.; Writing, Review and Editing, O.L.-K., D.M.C. and J.A.H. All authors have read and agreed to the published version of the manuscript.

Funding: The study has been supported by ACURF2017, Australian Catholic University, to Orly Lacham-Kaplan.

Conflicts of Interest: The authors declare no conflict of interest.

\section{Abbreviation}

$\begin{array}{ll}\text { Akt1 } & \text { serine/threonine kinase 1 } \\ \text { BSA } & \text { bovine serum albumin } \\ \text { DAPI } & 4^{\prime} \text {,6-diamidino-2-phenylindole } \\ \text { DMEM } & \text { Dulbecco's modified eagle medium } \\ \text { DEG } & \text { digital expression of genes } \\ \text { E2 } & \text { 17ß-estradiol } \\ \text { EPA } & \text { eicosapentaenoic acid } \\ \text { Er } \alpha & \text { E2 receptor alpha } \\ \text { Er } \beta & \text { E2 receptor beta } \\ \text { ERT } & \text { estrogen-based hormone replacement therapy } \\ \text { FBS } & \text { foetal bovine serum } \\ \text { FC } & \text { fold change } \\ \text { FDR } & \text { false discovery } \\ \text { GO } & \text { gene ontology } \\ \text { GFC } & \text { gene functional category } \\ \text { Gpr30 } & \text { G protein-coupled estrogen receptor-30 } \\ \text { h } & \text { hour } \\ \text { HRT } & \text { hormone replacement therapy } \\ \text { HS } & \text { horse serum } \\ \text { Mapk11 } & \text { mitogen-activated protein kinase 11 } \\ \text { Mrfs } & \text { myogenic regulatory factors } \\ \text { MyoD } & \text { myoblast determination protein } \\ \text { Myh1 } & \text { myosin heavy chain 1 } \\ \text { Myog } & \text { myogenin } \\ \mu \text { L } & \text { microliter } \\ \mu \text { M } & \text { micromolar } \\ \text { nM } & \text { nanomolar } \\ \text { n-3PUFA } & \text { 3n polyunsaturated fatty acids } \\ \text { NGS } & \text { next generation sequencing } \\ \text { PE } & \text { pathway enrichment } \\ \text { Pen/Strep } & \text { penicillin/streptomycin } \\ \text { qPCR } & \text { quantitative polymerase chain reaction } \\ \text { RNA } & \text { ribosomal nucleic acid } \\ \text { SCs } & \text { satellite cells } \\ \text { Tmem8c } & \text { transmembrane protein 8C } \\ & \end{array}$

\section{References}

1. Dumont, N.A.; Bentzinger, C.F.; Sincennes, M.C.; Rudnicki, M.A. Satellite Cells and Skeletal Muscle Regeneration. Compr. Physiol. 2015, 5, 1027-1059. [CrossRef] [PubMed]

2. Hernandez-Hernandez, J.M.; Garcia-Gonzalez, E.G.; Brun, C.E.; Rudnicki, M.A. The myogenic regulatory factors, determinants of muscle development, cell identity and regeneration. Semin. Cell Dev. Biol. 2017, 72, 10-18. [CrossRef] [PubMed]

3. Zammit, P.S. Function of the myogenic regulatory factors Myf5, MyoD, Myogenin and MRF4 in skeletal muscle, satellite cells and regenerative myogenesis. Semin. Cell Dev. Biol. 2017, 72, 19-32. [CrossRef] [PubMed]

4. McKenna, C.; Fry, C. Altered satellite cell dynamics accompany skeletal muscle atrophy during chronic. Curr. Opin. Clin. Nutr. Metab. Care 2017, 20, 447-452. [CrossRef] 
5. Laakkonen, E.K.; Soliymani, R.; Karvinen, S.; Kaprio, J.; Kujala, U.M.; Baumann, M.; Sipila, S.; Kovanen, V.; Lalowski, M. Estrogenic regulation of skeletal muscle proteome: a study of premenopausal women and postmenopausal MZ cotwins discordant for hormonal therapy. Aging Cell 2017, 16, 1276-1287. [CrossRef]

6. Qaisar, R.; Renaud, G.; Hedstrom, Y.; Pöllänen, E.; Ronkainen, P.; Kaprio, J.; Alen, M.; Sipilä, S.; Artemenko, K.; Bergquist, J. Hormone replacement therapy improves contractile function and myonuclear organization of single muscle fibres from postmenopausal monozygotic female twin pairs. J. Physiol. 2013, 591, 2333-2344. [CrossRef]

7. Tiidus, P.M.; Lowe, D.A.; Brown, M. Estrogen replacement and skeletal muscle: mechanisms and population health. J. Appl. Physiol. 2013, 115, 569-578. [CrossRef]

8. Toivonen, M.H.; Pöllänen, E.; Ahtiainen, M.; Suominen, H.; Taaffe, D.R.; Cheng, S.; Takala, T.; Kujala, U.M.; Tammi, M.I.; Sipilä, S. OGT and OGA expression in postmenopausal skeletal muscle associates with hormone replacement therapy and muscle cross-sectional area. Exp. Gerontol. 2013, 48, 1501-1504. [CrossRef]

9. Mohseni, R.; Aliakbar, S.; Abdollahi, A.; Yekaninejad, M.S.; Maghbooli, Z.; Mirzaei, K. Relationship between major dietary patterns and sarcopenia among menopausal women. Aging Clin. Exp. Res. 2017, 29, 1241-1248. [CrossRef]

10. Dupont, J.; Dedeyne, L.; Dalle, S.; Koppo, K.; Gielen, E. The role of omega-3 in the prevention and treatment of sarcopenia. Aging Clin Exp Res 2019, 31, 825-836. [CrossRef]

11. Rodacki, C.L.; Rodacki, A.L.; Pereira, G.; Naliwaiko, K.; Coelho, I.; Pequito, D.; Fernandes, L.C. Fish-oil supplementation enhances the effects of strength training in elderly women. Am. J. Clin. Nutr. 2012, 95, 428-436. [CrossRef] [PubMed]

12. Berio, E.; Divari, S.; Cucuzza, L.S.; Biolatti, B.; Cannizzo, F.T. $17 \beta$-estradiol upregulates oxytocin and the oxytocin receptor in C2C12 myotubes. PeerJ 2017, 5, e3124. [CrossRef] [PubMed]

13. Galluzzo, P.; Rastelli, C.; Bulzomi, P.; Acconcia, F.; Pallottini, V.; Marino, M. 17ß-Estradiol regulates the first steps of skeletal muscle cell differentiation via ER- $\alpha$-mediated signals. Am. J. Physiol.-Cell Physiol. 2009, 297, C1249-C1262. [CrossRef]

14. Magee, P.; Pearson, S.; Allen, J. The omega-3 fatty acid, eicosapentaenoic acid (EPA), prevents the damaging effects of tumour necrosis factor (TNF)-alpha during murine skeletal muscle cell differentiation. Lipids Health Dis. 2008, 7, 24. [CrossRef] [PubMed]

15. Murray, J.; Huss, J.M. Estrogen-related receptor $\alpha$ regulates skeletal myocyte differentiation via modulation of the ERK MAP kinase pathway. Am. J. Physiol.-Cell Physiol. 2011, 301, C630-C645. [CrossRef] [PubMed]

16. Saini, A.; Sharples, A.P.; Al-Shanti, N.; Stewart, C.E. Omega-3 fatty acid EPA improves regenerative capacity of mouse skeletal muscle cells exposed to saturated fat and inflammation. Biogerontology 2017, 18, 109-129. [CrossRef]

17. Ghnaimawi, S.; Shelby, S.; Baum, J.; Huang, Y. Effects of eicosapentaenoic acid and docosahexaenoic acid on C2C12 cell adipogenesis and inhibition of myotube formation. Anim. Cells Syst. 2019, 23, 355-364. [CrossRef]

18. Go, G.-Y.; Lee, S.-J.; Jo, A.; Lee, J.-R.; Kang, J.-S.; Yang, M.; Bae, G.-U. Bisphenol A and estradiol impede myoblast differentiation through down-regulating Akt signaling pathway. Toxicol. Lett. 2018, 292, 12-19. [CrossRef]

19. Hsueh, T.-Y.; Baum, J.I.; Huang, Y. Effect of eicosapentaenoic acid and docosahexaenoic acid on myogenesis and mitochondrial biosynthesis during murine skeletal muscle cell differentiation. Front. Nutr. 2018, 5, 15. [CrossRef]

20. Ogawa, M.; Yamaji, R.; Higashimura, Y.; Harada, N.; Ashida, H.; Nakano, Y.; Inui, H. 17 $\beta$-estradiol represses myogenic differentiation by increasing ubiquitin-specific peptidase 19 through estrogen receptor $\alpha$. J. Biol. Chem. 2011, 286, 41455-41465. [CrossRef]

21. Peng, Y.; Zheng, Y.; Zhang, Y.; Zhao, J.; Chang, F.; Lu, T.; Zhang, R.; Li, Q.; Hu, X.; Li, N. Different effects of omega-3 fatty acids on the cell cycle in C2C12 myoblast proliferation. Mol. Cell. Biochem. 2012, 367, 165-173. [CrossRef] [PubMed]

22. Zhang, J.; Xu, X.; Liu, Y.; Zhang, L.; Odle, J.; Lin, X.; Zhu, H.; Wang, X.; Liu, Y. EPA and DHA Inhibit Myogenesis and Downregulate the Expression of Muscle-related Genes in C2C12 Myoblasts. Genes 2019, 10, 64. [CrossRef] [PubMed]

23. Hatae, J.; Takami, N.; Lin, H.; Honda, A.; Inoue, R. 17ß-Estradiol-induced enhancement of estrogen receptor biosynthesis via MAPK pathway in mouse skeletal muscle myoblasts. J. Physiol. Sci. 2009, 59, 181-190. [CrossRef] [PubMed] 
24. Stark, K.D.; Holub, B.J. Differential eicosapentaenoic acid elevations and altered cardiovascular disease risk factor responses after supplementation with docosahexaenoic acid in postmenopausal women receiving and not receiving hormone replacement therapy. Am. J. Clin. Nutr. 2004, 79, 765-773. [CrossRef] [PubMed]

25. Stark, K.D.; Park, E.J.; Maines, V.A.; Holub, B.J. Effect of a fish-oil concentrate on serum lipids in postmenopausal women receiving and not receiving hormone replacement therapy in a placebo-controlled, double-blind trial. Am. J. Clin. Nutr. 2000, 72, 389-394. [CrossRef] [PubMed]

26. Wander, R.C.; Du, S.-H.; Ketchum, S.O.; Rowe, K.E. Effects of interaction of RRR-alpha-tocopheryl acetate and fish oil on low-density-lipoprotein oxidation in postmenopausal women with and without hormone-replacement therapy. Am. J. Clin. Nutr. 1996, 63, 184-193. [CrossRef]

27. Chen, Y.; Stegaev, V.; Kouri, V.P.; Sillat, T.; Chazot, P.L.; Stark, H.; Wen, J.G.; Konttinen, Y.T. Identification of histamine receptor subtypes in skeletal myogenesis. Mol. Med. Rep. 2015, 11, 2624-2630. [CrossRef]

28. Henderson, C.A.; Gomez, C.G.; Novak, S.M.; Mi-Mi, L.; Gregorio, C.C. Overview of the muscle cytoskeleton. Compr. Physiol. 2017, 7, 891-944.

29. Passey, S.L.; Bozinovski, S.; Vlahos, R.; Anderson, G.P.; Hansen, M.J. Serum amyloid A induces Toll-like receptor 2-dependent inflammatory cytokine expression and atrophy in C2C12 skeletal muscle myotubes. PLoS ONE 2016, 11, e0146882. [CrossRef]

30. Rall, J.A. What makes skeletal muscle striated? Discoveries in the endosarcomeric and exosarcomeric cytoskeleton. Adv. Physiol. Educ. 2018, 42, 672-684. [CrossRef]

31. Lee, E.J.; Nam, J.H.; Choi, I. Fibromodulin modulates myoblast differentiation by controlling calcium channel. Biochem. Biophys. Res. Commun. 2018, 503, 580-585. [CrossRef] [PubMed]

32. Taetzsch, T.; Tenga, M.J.; Valdez, G. Muscle fibers secrete FGFBP1 to slow degeneration of neuromuscular synapses during aging and progression of ALS. J. Neurosci. 2017, 37, 70-82. [CrossRef] [PubMed]

33. Liu, Z.; Wang, C.; Liu, X.; Kuang, S. Shisa2 regulates the fusion of muscle progenitors. Stem Cell Res. 2018, 31, 31-41. [CrossRef] [PubMed]

34. Runfola, V.; Sebastian, S.; Dilworth, F.J.; Gabellini, D. Rbfox proteins regulate tissue-specific alternative splicing of Mef2D required for muscle differentiation. J. Cell Sci. 2015, 128, 631-637. [CrossRef] [PubMed]

35. Lei, H.; Sun, Y.; Luo, Z.; Yourek, G.; Gui, H.; Yang, Y.; Su, D.-F.; Liu, X. Fatigue-induced orosomucoid 1 acts on CC chemokine receptor type 5 to enhance muscle endurance. Sci. Rep. 2016, 6, 18839. [CrossRef]

36. Shimba, S.; Wada, T.; Hara, S.; Tezuka, M. EPAS1 promotes adipose differentiation in 3T3-L1 cells. J. Biol. Chem. 2004, 279, 40946-40953. [CrossRef]

37. Rebalka, I.A.; Monaco, C.M.; Varah, N.E.; Berger, T.; D'souza, D.M.; Zhou, S.; Mak, T.W.; Hawke, T.J. Loss of the adipokine lipocalin-2 impairs satellite cell activation and skeletal muscle regeneration. Am. J. Physiol.-Cell Physiol. 2018, 315, C714-C721. [CrossRef]

38. Maffei, M.; Barone, I.; Scabia, G.; Santini, F. The multifaceted haptoglobin in the context of adipose tissue and metabolism. Endocr. Rev. 2016, 37, 403-416. [CrossRef]

39. Brandt, A.; Kania, J.; Reinholt, B.; Johnson, S. Human IL6 stimulates bovine satellite cell proliferation through a signal transducer and activator of transcription 3 (STAT3)-dependent mechanism. Domest. Anim. Endocrinol. 2018, 62, 32-38. [CrossRef]

40. Muñoz-Cánoves, P.; Scheele, C.; Pedersen, B.K.; Serrano, A.L. Interleukin-6 myokine signaling in skeletal muscle: a double-edged sword? FEBS J. 2013, 280, 4131-4148. [CrossRef]

41. Bennett, A.M.; Tonks, N.K. Regulation of distinct stages of skeletal muscle differentiation by mitogen-activated protein kinases. Science 1997, 278, 1288-1291. [CrossRef] [PubMed]

42. Jones, N.C.; Fedorov, Y.V.; Rosenthal, R.S.; Olwin, B.B. ERK1/2 is required for myoblast proliferation but is dispensable for muscle gene expression and cell fusion. J. Cell. Physiol. 2001, 186, 104-115. [CrossRef]

43. Millay, D.P.; Sutherland, L.B.; Bassel-Duby, R.; Olson, E.N. Myomaker is essential for muscle regeneration. Genes Dev. 2014, 28, 1641-1646. [CrossRef] [PubMed]

44. Weiss, A.; Leinwand, L.A. The mammalian myosin heavy chain gene family. Annu. Rev. Cell Dev. Biol. 1996, 12, 417-439. [CrossRef] [PubMed]

45. Eyster, K.M. The estrogen receptors: an overview from different perspectives. In Estrogen Receptors; Springer: Berlin/Heidelberg, Germany, 2016; pp. 1-10.

46. Ronda, A.C.; Boland, R.L. Intracellular distribution and involvement of GPR30 in the actions of E2 on C2C12 cells. J. Cell. Biochem. 2016, 117, 793-805. [CrossRef] [PubMed] 
47. Ronda, A.C.; Buitrago, C.; Boland, R. Role of estrogen receptors, PKC and Src in ERK2 and p38 MAPK signaling triggered by $17 \beta$-estradiol in skeletal muscle cells. J. Steroid Biochem. Mol. Biol. 2010, 122, 287-294. [CrossRef]

48. Ronda, A.C.; Vasconsuelo, A.; Boland, R. 17ß-estradiol protects mitochondrial functions through extracellular-signal-regulated kinase in C2C12 muscle cells. Cell. Physiol. Biochem. 2013, 32, 1011-1023. [CrossRef]

49. Cao, W.; Ma, Z.; Rasenick, M.M.; Yeh, S.; Yu, J. N-3 poly-unsaturated fatty acids shift estrogen signaling to inhibit human breast cancer cell growth. PLoS ONE 2012, 7, e52838. [CrossRef]

50. Brown, L.D. Endocrine regulation of fetal skeletal muscle growth: impact on future metabolic health. J. Endocr. 2014, 221, R13-R29. [CrossRef]

51. Berkane, N.; Liere, P.; Oudinet, J.-P.; Hertig, A.; Lefèvre, G.; Pluchino, N.; Schumacher, M.; Chabbert-Buffet, N. From pregnancy to preeclampsia: A key role for estrogens. Endocr. Rev. 2017, 38, 123-144. [CrossRef]

52. Schock, H.; Zeleniuch-Jacquotte, A.; Lundin, E.; Grankvist, K.; Lakso, H.-Å.; Idahl, A.; Lehtinen, M.; Surcel, H.-M.; Fortner, R.T. Hormone concentrations throughout uncomplicated pregnancies: a longitudinal study. BMC Pregnancy Childbirth 2016, 16, 146. [CrossRef] [PubMed]

53. Kawabata, T.; Kagawa, Y.; Kimura, F.; Miyazawa, T.; Saito, S.; Arima, T.; Nakai, K.; Yaegashi, N. Polyunsaturated Fatty Acid Levels in Maternal Erythrocytes of Japanese Women during Pregnancy and after Childbirth. Nutrients 2017, 9, 245. [CrossRef] [PubMed]

54. Coletta, J.M.; Bell, S.J.; Roman, A.S. Omega-3 fatty acids and pregnancy. Rev. Obstet. Gynecol. 2010, 3, 163-171. [PubMed]

55. Vahdaninia, M.; Mackenzie, H.; Dean, T.; Helps, S. The effectiveness of omega-3 polyunsaturated fatty acid interventions during pregnancy on obesity measures in the offspring: an up-to-date systematic review and meta-analysis. Eur. J. Nutr. 2018. [CrossRef]

56. Jones, M.L.; Mark, P.J.; Keelan, J.A.; Barden, A.; Mas, E.; Mori, T.A.; Waddell, B.J. Maternal dietary omega-3 fatty acid intake increases resolvin and protectin levels in the rat placenta. J. Lipid Res. 2013, 54, 2247-2254. [CrossRef]

57. Yaffe, D.; Saxel, O. A myogenic cell line with altered serum requirements for differentiation. Differentiation 1977, 7, 159-166. [CrossRef]

58. Guo, T.; Liu, W.; Konermann, A.; Gu, Z.; Cao, M.; Ding, Y. Estradiol modulates the expression pattern of myosin heavy chain subtypes via an ERalpha-mediated pathway in muscle-derived tissues and satellite cells. Cell. Physiol. Biochem. 2014, 33, 681-691. [CrossRef]

59. Saiti, D.; Lacham-Kaplan, O. Density gradients for the isolation of germ cells from embryoid bodies. Reprod. Biomed. Online 2008, 16, 730-740. [CrossRef]

60. Huang, D.W.; Sherman, B.T.; Zheng, X.; Yang, J.; Imamichi, T.; Stephens, R.; Lempicki, R.A. Extracting biological meaning from large gene lists with DAVID. Curr. Protoc. Bioinform. 2009, 27, 1-13. [CrossRef]

61. Fabregat, A.; Sidiropoulos, K.; Viteri, G.; Marin-Garcia, P.; Ping, P.; Stein, L.; D’Eustachio, P.; Hermjakob, H. Reactome diagram viewer: data structures and strategies to boost performance. Bioinformatics 2018, 34, 1208-1214. [CrossRef]

(C) 2020 by the authors. Licensee MDPI, Basel, Switzerland. This article is an open access article distributed under the terms and conditions of the Creative Commons Attribution (CC BY) license (http://creativecommons.org/licenses/by/4.0/). 